Kaygı, 31/2018: 57-91. Araştırma Makalesi | Research Article

Makale Geliş | Received: 10.07.2018

Makale Kabul | Accepted: 04.08.2018

Yayın Tarihi | Publication Date: 30.10 .2018

DOI: $10.20981 /$ kaygi.474283

\author{
Ömer AYGÜN \\ Dr. Öğr. Üyesi | Assist. Prof. Dr. \\ Galatasaray Üniversitesi, Fen-Edebiyat Fakültesi, Felsefe Bölümü, İstanbul, TR \\ Galatasaray University, Faculty of Arts and Sciences, Department of Philosophy, İstanbul, TR \\ ORCID: 0000-0002-2552-9862 \\ omeraygun@gmail.com
}

\title{
Yaygın Platon Okumasının Bir Eleştirisi
}

\section{$\ddot{O ̈ z}$}

$\mathrm{Bu}$ makale, yaygın Platon okumasının Platon metinlerinin şeklini göz ardı etmesini eleștirmektedir. Platon metinlerinin şekli, Platon'un felsefi kariyerinin başından sonuna kullandığı diyalog şeklidir. Bu makale diyalog şeklini görmezden gelen hiçbir Platon okumasının geçerli olamayacağını savunmaktadır. Bunun için ilk bölümde yaygın Platon okuması diyalogları kronolojik olarak ayırdığı üç grup aracılığıyla özetlenmekte ve bu okumanın güçlü yanları vurgulanmaktadır. İkinci bölümde bu yaygın okuma, önce Platon metinlerinin iki yönlü yapısı ve bunun sonucu olarak Platon alımlama tarihindeki iki eğilim ışığında nitelendirilmekte ve yaygın okumanın "gelişimci dogmatik" bir okuma olduğu ileri sürülmektedir. Üçüncü bölüm bu niteliklere sahip bir okuma olarak yaygın okumanın varsayımlarını ortaya çıkarmakta ve eleştirmektedir; genel olarak yaygın okumanın bir saf rasyonalite varsayımıyla işe başladığı savunulmakta ve bu nedenle söylem düzeyleri, tarihlendirme ölçütleri ve tarihlendirme düzlemleri arasında silikleştirdiği ayrımların altı çizilmektedir. Makaledeki eleştirinin temelinde diyalog şekli olduğundan, Platon metinlerinde diyalog şeklinin göz ardı edilmemesi gerektiğine ilişkin ek göstergelere işaret edilmektedir. Son bölümde bu makaleyi tamamlayacak üç çalışma tanımlanmaktadır.

Anahtar Kelimeler: Antikçağ Felsefesi, Platon, Diyalog, Yazı.

\section{A Critique of the Standard Plato Reading}

\begin{abstract}
This paper criticizes the standard Plato reading strategy for its neglect of the form of Plato's writings. The form of Plato's writings is the dialogue form which he employed throughout his philosophical career. In this paper, we argue that no Plato reading is valid unless it takes into account this dialogue form. To this end, in the first part of the paper, we offer a very rough summary of the standard Plato reading with its three-part distinction between the dialogues according to their chronology, and then underline the strengths of this standard reading. In the second part, we qualify the standard Plato reading in light of, first, the persistent two-aspect character of Plato's text, and, then, the consequent two trends of reading along the history of the reception of Plato's philosophy. For this brief survey, we claim that the standard Plato reading is a dogmatic developmentalist reading. In light of this characterization, the third part draws out and criticizes the presuppositions of the standard Plato reading; generally speaking, we claim, first, that the standard reading starts out by imposing a model of pure rationality onto Plato's texts, and, second, that it thereby blurs many important distinctions between different levels of discourse, dating criteria, and kinds of date. Since the paper's criticism emphasizes the dialogue form in Platro's writings, we point to three Platonic passages which suggest that the dialogue form should not be overlooked. Finally, the paper ends by defining three studies to supplement the present research.
\end{abstract}

Keywords: Ancient Philosophy, Plato, Dialogue, Writing. 


\section{Giriş}

Platon felsefi kariyeri boyunca neredeyse hep diyalog yazmıştır, üstelik neredeyse yalnızca diyalog yazmıştır. Bu makale yaygın Platon okumasının bu olguyu göz ardı etmesini eleştirmektedir. Bunun için ilk bölümde (1) yaygın Platon okuması diyalogları kronolojik olarak ayırdığı üç grup aracılığıyla özetlenmekte ve bu okumanın güçlü yanları vurgulanmaktadır. İkinci bölümde (2) bu yaygın okuma iki açıdan nitelendirilmektedir: yaygın okuma önce Platon metinlerinin dramatik ve argümantatif olarak iki yönlü yapısı 1şı̆̆ında değerlendirilmekte, ardından bunun sonucu olarak Platon alımlama tarihindeki iki eğilim olan dogmatik okuma ve kuşkucu okuma ayrımı bakımından konumlandırılmakta ve sonuç olarak "gelişimci dogmatik" bir okuma diye nitelendirilmektedir. Üçüncü bölüm (3) gelişimci dogmatik bir okuma olarak yaygın okumanın varsayımlarını ortaya çıkarmakta ve eleştirmektedir; genel olarak yaygın okumanın gerekçesiz bir şekilde bir "soyut rasyonalite" varsayımıyla işe başladığ savunulmakta ve bu nedenle söylem düzeyleri, tarihlendirme ölçütleri ve tarihlendirme düzlemleri arasındaki ayrımları gerekçesizce silikleştirdiği ileri sürülmektedir. Makaledeki eleştirinin temelinde diyalog şekli olduğundan, dördüncü bölümde (4) Platon metinlerinde diyalog şeklinin göz ardı edilmemesi gerektiğine ilişkin üç pasaj "Platonik jest" kavramı altında incelenmekte, beşinci ve son bölümde (5) bu makaleyi tamamlayacak üç çalışmanın taslağı çıkarılmaktadır: öncelikle buradaki olumsuz önerileri ve eleştirileri tamamalayacak olumlu ve yapıcı bir Platon okuması ortaya koyulmalı, ardından bu okumanın yaygın okumaya olan üstünlügü Platon metinlerinden örnekler üzerinde gösterilmeli, son olarak da Platon'un gerek Pythagoras, Parmenides ve Sokrates gibi öncelleriyle, gerekse Aristoteles ve Akademi müdürleri gibi ardıllarıyla ilişkileri yaygın okumanın varsayımlarından bağımsız olarak yeniden tanımlanmalıdır.

Platon'u görür görmez tanırız: bu dünyayı işaret eden öğrencisi Aristoteles'in karşısında eliyle gökyüzünü gösteren filozoftur o. Bu makalede bu Platon imajını ve bu Platon-Aristoteles ilişkisini sorgulamayı teklif ediyoruz. 


\section{Yaygın Platon Okuması}

Yaygın Platon okumasını özetlemekle başlayalım. ${ }^{1}$ Yaygın okumanın özelliği ve, göreceğimiz gibi, en büyük avantajı, Platon’un yaşamını, diyaloglarını ve "felsefi sistemini” örtüştürmesidir. Bu okumada diyaloglar yazılış tarihlerine göre üç döneme ayrılır, bunlar Platon'un yaşamının ve felsefi kariyerinin ana duraklarına denk gelir:

Erken Dönem Diyalogları: İlk dönemde Sokrates'in merkezde olduğu, etik kavramları ele alan ve sıklıkla da sonuçsuz biten "erken dönem diyalogları" vardır. Bunlar kuşkucu okumaya elverişli olduğunu gördüğümüz "aporetik" ya da "Sokratik" diyaloglardir.

Olgunluk Dönemi Diyaloglart: Bunlarda Platon Sokrates’in düşüncesinin ve davasının etkisinden uzaklaşıp kendi felsefi öğretisini kurmaya başlar. Bu öğreti elbette İdealar Teorisi'dir. (Buna "Platoncu ikicilik" ya da "Platoncu idealizm" ad1 da verilebilir.) Özellikle Devlet ve Phaidon diyaloglarında geliştirilen İdealar Teorisi’nin kozmogonik, fizik ve teolojik sonuçları Timaios'ta çıkarılırken, öte yandan da epistemolojik karşılıkları özellikle Phaidon'da ve Menon'da dile getirilen "hatırlama", “ruh göçü” ve “doğuştan fikirler” öğretileriyle çıkarsanmaktadır. İdealar Teorisi’nin etik boyutu zaten Sokrates'in tartışmalarından devralınmıştır: erdemin öğretilebilip öğretilemeyeceği sorusu, sofistle filozofun ayırt edilmesi sorunu, tanıma ilişkin sorunlar... İdealar Teorisi'yle birlikte Platon bu etik boyuta bir politik felsefe öğretisi eklemiş gibidir: Yasalar ya da Devlet Adamı gibi diyaloglarla desteklense de büyük ölçüde Devlet diyaloğunda karşımıza çıkan ütopyacı İdeal Devlet öğretisi. İdealar Teorisi'nin merkezde bulunduğu bu öğretiler bütününe Platon'un estetikle, eğitimle, Tanrı'yla ve dille ilgili öğretileri de eklenince, karşımıza az çok tutarlı, büyük bir felsefe sistemi çıkmaktadır.

\footnotetext{
${ }^{1}$ Makaledeki bütün çeviriler, tersi belirtilmedikçe, tarafımıza aittir. Makalede kullanılan "yaygın Platon okuması" deyiminin belirsizliğini kabul ediyoruz. Ancak bu belirsizlik bir ölçüde yaygın olma özelliğinden kaynaklanmaktadır. Yine de bu makaledeki eleştirilerin ileride Platon metinlerinin nasıl okunmamasından çok nasıl okunması gerektiğine yönelik yapıcı bir makaleye temel oluşturduğu, yani buradaki eleştirinin bir tür zemin hazırlığı olduğu akılda tutulmalıdır.
} 
Yaşlılık Dönemi Diyalogları: Platon'un yaşlılığına tarihlendirilen bu diyaloglarda İdealar Teorisi'ne yönelik eleştiriler ve İdealar Teorisi'nin ötesinde araştırmalar karşımıza çıkar - özellikle Parmenides, Sofist, Philebos, Yasalar gibi diyaloglarda.

Yaygın Platon okuma çerçevesinin ilk avantajı, tarihsel olguları temel almasıdır: yaygın okuma çerçevesi bir yere kadar Sokrates'in, ama tabii ki en çok Platon'un yaşamöyküsünün belli dönemeçlerine dayanır: Sokrates'le tanışması, Sokrates'in davası, Sicilya yolculukları, Akademi'nin kuruluşu gibi. Çerçevenin ikinci avantajı, tek bir öğretinin (İdealar Teorisi'nin) evveliyatı, kuruluşu ve çürütülmesi gibi hem mantıksal hem çarpıcı üç durak sergilemesidir. Bununla bağlantılı olarak, ileride göreceğimiz çoğu okuma çerçevesinden farklı olarak, yaygın Platon okuma çerçevesi Platon'un diyaloglarının tümüne yer verebilecek genişlikte ve esnekliktedir. Çerçevenin üçüncü ve en büyük avantaj1, bu iki avantajı birleştirerek Platon'un dönemini, yaşamöyküsünü, hatta öncellerini ve ardıllarını Platon'un felsefesiyle kolayca örtüştürebilmemizi sağlamasıdır. Örneğin yaygın okuma çerçevesinde Peloponnessos Savaşları'nın tarihi Sokrates'in davasına 1şık tutar, o davanın akibeti tabii ki Platon'un erken dönem diyaloglarını anlamamızı kolaylaştırır; benzer şekilde Platon’un Akademi'deki kurumsal etkinliği, olgunluk dönemindeki epistemolojisini ve pedagojisini yansıtır; Platon'un Sicilya'da yaşadığı büyük hayal kırıklığı İdealar Teorisi'ndeki ve İdeal Devlet projesindeki sorunların belirtisi ve geç yaştaki kuşkuculuğunun habercisidir.

Aslında yaygın Platon okuma çerçevesi o kadar sağlamdır ki yaygın bir Aristoteles okuma çerçevesinin hem içeriğinin hem yönteminin tohumlarını da barındırır. Nasıl Platon'un felsefi kariyeri Sokrates'in baskın olduğu dönem, Platon'un kendini bulduğu dönem ve son olarak da kendini eleştirdiği dönem olarak üçe ayrılmışsa, Aristoteles'in felsefi kariyeri de Platon'un baskın olduğu dönem, ardından Aristoteles'in hocasının etkisinden sıyrılmak için çabaladığı dönem ve sonunda olgunlaştığ dönem olarak okumasından oluşacaktır. Buna göre, hocasının idealist olgunluk döneminde Akademi'de olan Aristoteles, işe idealist ve teolojik yönü ağır basan metinlerle başlamış, Platon'un ölümüyle birlikte Atina'dan ayrılıp Platoncu 
felsefeyi reddetmiş, en sonunda da daha "bilimsel”, "dünyevi”, gerçekçi ve olgucu bir öğreti oluşturmuştur. Bu durumda Platon'la Aristoteles'in felsefi kariyerleri benzer bir seyir izler: Önce bir hoca karşısında itaat/taklit/hayranlık dönemi, sonra bir ayrılma ve bağımsızlık dönemi, sonunda da bir ağırbaşl1lık/ölçülülük/hocalık dönemi. Tahmin edilebileceği gibi bu şema ileriye doğru Theophrastos'u ve geriye doğru Sokrates'i ve tabii Parmenides'i içerebilecek kadar sağlamdır.

\section{Yaygın Platon Okumasının Nitelendirilmesi}

Yaygın okumanın biraz fazla sağlam olduğu, yani doğru olamayacak iyi olduğu sezilmiş olabilir. Bu sağlıklı kuşkuya kulak verelim ve yaygın okumanın varsayımlarını ortaya çıkaralım. Ancak bunu yapmak için önce yaygın okumanın niteliklerini çıkarsayalım. Bunu önce Platon metinlerinin ikiyönlü yapısından, sonra da Platon alımlama tarihinin iki eğiliminden hareketle yapacağız.

Bugün Platon'dan elimize kalan metinler 600.000 sözcük kadardır ve bunlar paleografik açıdan iyi durumdadır. ${ }^{2} \mathrm{Bu}$ metinlerin neredeyse tamamında argümantatif yönün yanısıra bir dramatik yön vardır. Zira mektupları saymazsak Platon'un metinlerinin neredeyse tamamı diyalog şeklinde yazılmıştır. Platon yaşamı ve felsefi kariyeri boyunca tutarlı ve neredeyse ödünsüz bir ifade şekli seçimi yapmıştır: diyalog şekli. Üstelik diyalogların neredeyse tamamı dramatik diyaloglardır, çünkü bu diyaloglar, kurmaca olsun olmasın, tarihsel değer ya da iddia taşısın taşımasın, dramatik öğeler barındırırlar: konuşan karakterlerin belli isimleri, belli kişilikleri, belli farklı sosyo-ekonomik arkaplanları, belli varsayım ve beklentileri vardır; sıklıkla belli bir dramatik tarih ve belli bir yerde bulunurlar. Bu haliyle Platon diyalogları, şekil olarak, bir felsefe makalesinden çok, bir tiyatro oyununu andırır.

Ancak, şekli bir yana bıraktığımızda, Platon diyaloglarının bir tiyatro oyunundan farkı diyaloglarda geçen konuşmaların içeriği ve yöntemidir: hikayelere ya da

\footnotetext{
2 Palegrafi ve elyazması aktarımı için $b k z$. Irigoin 1997: 145-190; Thrasyllos'un "kanonu" ve ilgili tartışmalar için $b k z$. Cooper \& Hutchinson 1997: vii-xxvi.
} 
benzetmelere başvurulsa da, bu içerik felsefi ve kavramsal bir içeriktir, hatta bu içerik de tipik olarak etik, politika ve psikolojiyle ilgilidir. Diyalogların bu kavramsal içeriği neredeyse her zaman bir soru-yanıt yöntemi çerçevesinde karşımıza çıkar. ${ }^{3}$ Farklı diyaloglarda bu sorunun akibeti farklıdır: bazen soru yanıtlanmadan sonuçsuz kalır ya da yanıt adayları çürütülmekle kalır; bazen soru yapıcı şekilde yanıtlanır, yanıt öğreti haline gelir, hatta başka diyaloglardaki başka yanıtlarla bütünleşerek bir sistem oluşturur; bazen de o öğretinin kendisinde yeni bir soru ve sorun ortaya çıkar.

O halde Platon metinlerinin hepsinde bu iki yönü az çok buluyoruz: dramatik yön ve argümantatif yön. Platon metinlerine içkin olan bu yapısal ikilik, Platon alımlama tarihine de damgasını basmış gibi görünüyor. ${ }^{4}$ Platon'un ilk ardıllarından itibaren çatışma halinde olan iki okuma karşımıza çıkıyor: dogmatik okuma ve kuşkucu okuma. Dogmatik okuma diyalogların argümantatif yönünü, kuşkucu okuma ise dramatik yönünü önplana çıkaran okumadır. Bu iki okumayı sırasıyla görelim.

\section{a. Dogmatik Okuma}

Bir yanda "dogmatik" okuma vardır. ${ }^{5}$ Bu okuma Platon metinlerinin dramatik yönünü (özellikle de diyalog şeklini) ikincilleştirip ya da yoksayıp argümantatif yönünü tekelleştirir; Platon'un felsefi bir sisteminin olduğunu ve diyalogların da bir şekilde bu sistemin dişavurumu olduğunu düşünür. Dogmatik okuma Platon metinlerini büyük ölçüde dramatik yönlerinden koparır; onları bir argümanlar dizisi gibi, bir tutarlı önermeler bütünü, hatta tamamlayıcı öğretiler bütünü, yani bir felsefi sistem olmaya çalışan metinler gibi görür ve öyle değerlendirir.

\footnotetext{
${ }^{3}$ Her diyalog soru-yanıt şeklinde ilerlemek zorunda değildir; konuşmacılar sırayla uzun uzun konuşmalar da yapabilirler. Bu "diyalog" türü belki karşılıklı monoloğu andırsa da kısmen Symposion'da ve Phaidros'ta, tabii ki Sokrates'in Savunması'nda, Kleitophon'da karşımıza çıkar, hatta Protagoras'ta açıkça tartışılır. Aşağıda dördüncü bölümde göreceğimiz gibi Protagoras uzun konuşmalı "diyaloğu" tercih ederken Sokrates sorulu-yanıtlı diyaloğu tercih edecektir.

${ }^{4}$ Aşağıda yalnızca yaygın okumayı nitelendirmek amacıyla değineceğimiz Platon alımlama tarihi için başvurduğumuz kaynaklar Tigerstedt 1974, Tigerstedt 1977 ve Gonzalez 1995'tir. Okur bu tarihle ilgili daha çok bilgi için bu kaynaklara başvurmalıdır.

5 "Dogmatik okuma" deyimindeki "dogmatik" sıfatı, "katı görüşlü” ya da "dar görüşlü” gibi olumsuz anlamlarıyla değil, felsefedeki teknik anlamıyla anlaşılmalıdır: Platon'un felsefi sistemi hakkında bir "fikri”, bir "önerisi”, bir "görüşü" olan bir okumadır bu, o kadar.
} 
Dogmatik okuma Platon alımlama tarihinde başat okumadır - hem en eski okumadır, hem en büyük coğrafi ve kültürel çeşitliği entegre edebilen okumadır, hem de en kesintisiz okumadır. Bugün yaygın Platon okumasının da zaten bir dogmatik okuma olduğunu giderek daha iyi göreceğiz. Dogmatik okumanın alttürlerine bakarak bugünkü yaygın Platon okumasını daha da kesin bir şekilde nitelendirelim.

Saf Dogmatik Okuma: Dogmatik Platon okumas1, ta Eski Akademi'nin, Aristoteles ve Eudoksos'un benimsediği okumadır, Orta ve Yeni Akademi’yi saymazsak, neredeyse kesintisiz bir gelenek oluşturur. Yeni-Platonculukta, Augustinus'ta, Atina'daki Yeni-Platoncu Akademi'de, Beyt-ül Hikme'de, Chartres Okulu'nda, Rönesans Platonculuğunda Platon denince akla belli başlı ögretiler gelir, yalnızca bu öğretiler gelir, hatta bu öğretilerden oluşan tek bir felsefi sistem gelir. Kepler'in ya da Galileo'nun zihnindeki Platon da bundan farklı değildir. İoannes Serranus bile son çözümlemede Yeni-Platonculuğun dogmatik okumasına döner. ${ }^{6}$

Platon'un bu öğretileri elbette başka pozisyonlarla karşıtlık içerisinde kavranır: Aristoteles'inkilerle, Aristotelesçiliğinkilerle, sofistlerinkilerle, şairlerinkilerle, Homeros'unkilerle ya da büyük tektanrılı dinlerinkilerle... Kimsenin istese de artık hafızasından söküp atamayacağı Raffaello'nun Atina Okulu'nda bu özellikler hemen kendini gösterir: Platon bizzat bir taraf tutmaktadır, daha doğrusu bir tarafa işaret etmektedir; karşısında da Aristoteles başka bir taraf tutmakta, başka bir yöne işaret etmektedir. $^{7}$

Yeni-Platoncu okumanın ve belki bütün saf dogmatik okumaların bir zaafı seçici olmalarıdır: Plotinos'un favori diyalogları vardır (Symposion, Phaidros, Phaidon, Devlet...) ve Platon'un öğretisini o diyaloglardan çıkarsar, ancak o öğretiyi içermeyen ya da karşıt öğreti içeren diyaloglardan söz etmez. 1578'de Stephanus'un Platon

\footnotetext{
${ }^{6}$ Tigerstedt 1974: 7 ile karşılaştırını: "Bu Platonculuğun tamamen yoksun olduğu şey, Platon'daki Sokratik, aporetik öğeydi; bu öğe, bu filozofların [Orta Platoncuların] ve teologların hiçbir işine yaramiyordu."

${ }^{7}$ Kesin konuşmak gerekirse, freskteki karşıtlık, Platon'un yukarıyı göstermesiyle Aristoteles'in aşağıyı göstermesi arasında değildir, Platon'un dikey düzlemde yukarıyı göstermesiyle Aristoteles'in yatay düzlemde ileriyi işaret etmesi arasındadır. Benzer bir karşıtlık Platon'un elindeki Timaios kitabının duruşuyla Aristoteles' in elindeki "Ethica"nın duruşu arasında fark edilebilir.
} 
basımının Platon'un özellikle Yeni-Platonculuk damgası taşıyan saf dogmatik okumadan kurtarılması projesinin bir parçası olması anlamlıdır. Benzer şekilde Hıristiyanlık sonrası Platon alımlamasında tabii ki teolojik tartışmalar baskındır ve bu bağlamda Platon denince akla hemen Timaios diyaloğu, hatta o diyalogdaki uzun anlatı gelir. Raffaello'nun freskinde Platon'un Timaios'la "simgelenmesi” boşuna değildir. Saf dogmatik okumanın Platon'un Timaios diyaloğuna, daha doğrusu o diyalogdaki anlatıya odaklanması, "olası bir hikaye” (eikos mythos) ve "olası bir açıklama” (eikos $\log o s$ ) (29c) olduğu açıkça söylenen bu anlatıyı kozmolojik bir öğretiye dönüştürmesi dışsal bir olguyla da bağlantılıdır: Doğu Roma toprakları dışında Ortaçağda uzun süre boyunca Platon'un yaygın dolaşımda olan tek eseri Timaios diyaloğunun ilk bölümünün Chalcidius çevirisi ve şerhiydi. Dolayısıyla 12. yüzyılda Henricus Aristippus'un tek tük çevirilerine rağmen, Ficino'nun çeviri ve şerhlerine kadar Batı Roma topraklarında Platon'un okunacak başka bir metni yoktu. Bununla birlikte bu Ortaçağ Timaios'unun son derece yaygın bir şekilde okunduğunu ve tartışıldığını eklemek gerekir. Saf dogmatik okumanın elinde Batıda belki tek bir Platon metni vardı, ancak o metin de saf dogmatik okumaya son derece yatkındı ve tabii ki büyük tektanrılı dinlerin öğretileriyle bir diyaloğa son derece elverişliydi.

Ĕgitimsel Dogmatik Okuma: Dogmatik okumada bir çığır açılması için ta 19. yüzyılın başını, Schleiermacher'in çalışmalarını beklemek gerekir. Saf dogmatik okumalardan farklı olarak Schleiermacher'e göre hem bütün diyaloglar hesaba katılmalıdır, hem de, en önemlisi, diyalogların içeriği şeklinden bağımsız düşünülmemelidir. ${ }^{8}$ Şekli hesaba kattığımızda da diyaloglara bakışımız değişir, artık onları tek bir sistemin aşamalı pedagojik sunumu olarak görürüz. Yani Platon külliyatı saf bir öğreti olmadan önce bir müfredattır: başlangıçta yöntem, mantık ve epistemoloji "dersleri" vardır; ardından etik ve fizik "dersleri” gelir; en sonda da yapıcı bilimsel sunumun kendisi. Ancak diyaloglarda dile getirilen görüşler arasındaki çelişkileri açıklamakta Schleiermacher'in yaklaşımının başarılı olmadığg düşünülebilir. Bir

\footnotetext{
${ }^{8}$ Özellikle bkz. Schleiermacher, 1836: 19. Bizim burada savunduğumuz okuma ve yaygın okumaya getirdiğimiz eleştiriler özgün olmaktan uzaktır ve son çözümlemede Schleiermacher'in çalışmalarına dayanır.
} 
müfredatın farklı görüşler içermesi normaldir, ancak karşıt görüşler içermesi kafa karıştırıcı bulunabilir.

Gelişimci Dogmatik Okuma: Bu noktada Hermann, Platon'un diyaloglarına yekpare bir öğreti ya da hazır bir müfredat olarak değil, tek bir sistemin gelişiminin kayıtları olarak bakmayı önermiştir. Gelişimcilik (developmentalism ya da geneticism) 20. yüzyılda da benimsenecek ve stilometrik çalışmalarla desteklenecektir. Platon'un farklı diyaloglarında karakterlerin (sıklıkla da Sokrates'in) karşıt görüşler ileri sürmesinin nedeni, bu okumaya göre, Platon'un zaman içinde fikir değiştirmiş olmasıdır. Buna göre bazı diyaloglarda içerik ve yöntem olarak toy bir Platon görürüz; bazı diyaloglarda ise belli bir felsefi sistem kuran ve onun merkezine İdealar Teorisi'ni yerleştirmiş bir Platon buluruz; bazı diyaloglarda ise İdealar Teorisi'nin eleştirisiyle karşılaşırız. Birazdan göreceğimiz gibi, bizim bu makalede eleştirmek istediğimiz yaygın Platon okuması bu türe girmekte, "dogmatik" okumalar arasında "gelişimci" sıfatı taşımaktadır.

Tübingen Okulu: Yakın zamanlara kadar gelişimci dogmatik okumayla rekabet etmeye aday olabilecek tek okuma Tübingen Okulu'nunkiydi. Gelişimci okuma, Platon'un tek felsefi sisteminin diyalogların neresinde bulunduğu sorusuna yanıt bulmakta zorlanabilir. Tübingen Okulu'na göre ise sistem diyaloglarda değildir ki diyalogdan diyaloğa gelişsin. Diyaloglar tek sistemin önhazırlığından öte bir şey değildir. Peki Platon'un felsefi sistemi diyaloglarda değilse nerededir? Platon'un ünlü “sözlü öğretileri”nde, yazılmamış öğretilerinde. Dolayısıyla bu okuma, diyalogların “egzoterik”, yani kamusal tartışmalarının ardında, Platon’un “ezoterik” bir öğretisi olduğunu savunmaktadır. Tahmin edilebileceği gibi bu okuma Platon’un asıl öğretisini Aristoteles'teki ve ikincil literatürdeki pasajlarda aramaya koyulmaktadır. Bu okumayı tehdit eden bir sorun, Platon metinlerini okumayı neredeyse gereksiz k1labilmesi, yani bir Platon okuma yöntemi kadar Platon okumama yöntemine dönüşebilmesidir. 


\section{b. Kuşkucu Okuma}

Dogmatik okumaların hepsine alternatif bir Platon okuması da vardır. Dogmatik okuma nasıl Platon'un metinlerinin argümantatif yönünü önplana çıkarmışsa, bu alternatif okuma Platon metinlerinin dramatik yönüne odaklanır. Bu okuma, Platon'un diyaloglarını, değil bir felsefi sistemin, kavramsal bir iddianın bile ileri sürülmesi olarak görmekten kaçınır. $\mathrm{Bu}$ nedenle bu okumaya "kuşkucu okuma" adı verilebilir. Bu okumanın simgesi, Cicero'nun Platon hakkındaki şu sözüdür:

[Platon'un] kitaplarında bir şey olumlanmak yerine, lehte ve aleyhte birçok sorun masaya yatırılır, her konuda soru sorulur ama kesin hiçbir şey söylenmez. (Cicero, Academica I.46)

Argümantatif yönü göz ardı edilen bir Platon metninden geriye ne kalır? Sonuçsuz olsa da hoş bir tartışma, hikayeler, canlı karakterler, enfes bir dil kullanımı, retorik öğeler, şiirsel öğeler, tarihsel ve sosyo-politik öğeler, bir takım sayısal ya da etimolojik şifreler...

Yukarıda bazı Platon diyaloglarının zaten sonuçsuz kaldığını, sorulan soruya yapıcı bir yanıt verilemediğini, bir dizi yanıt adayının önerilip hepsinin güya çürütüldüğünü görmüştük. ${ }^{9}$ İşte kuşkucu okuma böyle diyaloglara çok uygundur. Nitekim dogmatik okuma tersini düşünmeye bizi alıştırsa da, Sokrates ve Platon ile kuşkuculuk arasında güçlü bağlar vardır. Tarihsel Sokrates'in felsefi tutumu kuşkuculuktan uzak değildir. Zaten kuşkucu felsefe okulu olarak Skeptikler öncelleri olarak Sokrates'i kabul ederler. Sokrates'in hiçbir şey yazmamış olması, Platon'un hiçbir şeyi kendi ă̆zından yazmamış olması ve yazdıklarında geçen yazı eleştirisi ${ }^{10}$ kuşkuculuğu çağrıştıran olgulardır. Son olarak da Platon'un Akademi'sinin orta döneminde başında bulunan Arkesilaos'la birlikte Platoncu öğretiler kuşkucu bir tutum içinde dağılıp eriyecektir. Long ve Sedley'nin dediği gibi:

\footnotetext{
${ }^{9}$ Burada "güya" dememizin nedeni, birçok diyalogda sahte zafer ve sahte bozgunlar olmasıdır: Platon diyaloglarında bir iddianın geçersiz bir argümanla karşı iddiaya "galip" ilan edildiği ve gene bir iddia geçersiz bir çürütmeyle "mağlup" ilan edildiği sikça olur. Benzer şekilde birçok diyalogda (örneğin Devlet'in I. kitabının sonunda) galibiyet-mağlubiyet ekseninin ve tartışmayı kazanma isteğinin (philotimia'nın) ötesine geçme zorunluluğu dile getirir.

${ }^{10}$ Özellikle Phaidros, 274c ve devamına, ayrıca Yedinci Mektup, 341c ve devamına bakını.
} 
Ancak Akademi'nin içerisinde Platoncu öğreti itici gücünü büyük ölçüde yitirmişti; [Arkesilaos] Platon'un erken dönem yapıtlarındaki eleştirel diyalektiğe dönmüştü ve ancak bu sayede nihayet okula gençlik aşısı yapabilmişti. Onun yönetiminde "Yeni Akademi" başat kuşkucu okul statüsünü kazanmıştı (Long ve Sedley 1987: 5).

Nitekim tarihte kuşkucu okumanın temsilcilerine örnek olarak en erken Orta Akademi'de Arkesilaos ve Yeni Akademi'de Karneades ve Larissalı Philon verilebilir. $\mathrm{Bu}$ sonuncusu, yukarıda Platon hakkındaki "kuşkucu" fikirlerini okuduğumuz Cicero'nun da hocasıdır.

Sokrates'le, Platon'la ve Akademi'yle kuşkucu okuma arasında birçok ilişki olmasına rağmen, kuşkucu okuma bazı diyalogları kolayca açıklayabilmekle birlikte şu soruları yanıtlamakta zorlanmaktadır: Hiç de sonuçsuz kalmayan, hatta bir öğreti önerir gibi duran diyaloglara ne diyeceğiz? Wieland'ın Ideen ohne Ideenlehre deyimine benzer şekilde, diyaloglarda İdeaların bulunduğunu ama bir “İdealar Öğretisi”nin bulunmadığını söylemekle tatmin olacak mıyız? İdealar, değişime rağmen sabitliği, algılara rağmen bilgiyi temellendirmek için kullanılıyorsa, burada bir öğretiden, teoriden ve hatta felsefi sistemden söz etmekten ne kadar kaçınabiliriz ve neden kaçınalım? İdeaları alıp İdealar Teorisi’ni ya da İdealar Öğretisi’ni almamak mümkün müdür? Ayrıca eğer diyaloglarda hiçbir öğreti yoksa, o öğretileri eleştiren diyaloglara ne anlam vereceğiz? Belli öğretileri eleştiren diyalogları o öğretileri ileri süren diyaloglara karşı kullanacak olursa, kuşkucu okuma tıpkı saf dogmatik okuma gibi gerekçesiz bir seçiciliğe düşmüş olmayacak mıdır? ${ }^{11}$ Kaldı ki bir tartışmada iddialar, öğretiler ve nihayetinde bir sistem olmadığını ileri sürmek, aynı tartışmanın konunun hakikatine ilişkin bir öğretiye ve hatta başka öğretilerle tutarlı ve ortak bir sisteme yönelik olmadığını ileri sürmeyi gerektirmez. Başka bir deyişle, kuşkucu okuma diyaloglarda hiçbir öğreti olmadı ̆̆ını kanıtlasa bile, diyaloglarda bir öğretiye yönelik bir tutum olmadığ anlamına gelmez bu: konunun hakikatini ifade eden öğretiye yönelik olmayan bir tartışma yönsüz ve amaçsız bir konuşmadır, felsefi içerikten yoksundur ve ciddi anlamda bir itirazı, eleştiriyi ya da fikir değiştirmeyi olanaksız kılar. Oysa

\footnotetext{
${ }^{11}$ Çok farklı bir bağlamda olsa buna benzer endişeler için $b k z$. Burnyeat 1985: 30-36 ve Recco 2010: 2-6.
} 
Platon'un diyaloglarını ciddi itirazdan, çürütücü eleştiriden ve fikir değişikliği olasılığından yoksun bırakan bir okuma, başarısızlığa mahkum görünmektedir. Kuşkucu okumanın dogmatik okumaya göre marjinal olması rastlantı değildir.

Artık şunu sorabiliriz: Yaygın Platon okuması Platon alımlama tarihinde nereye denk düşer? Yaygın Platon okumasını nasıl nitelendirmek gerekir? Platon'un metinlerinin iki yönünü incelediğimize ve bu iki yönü tekelleştiren iki Platon okumasının izini tarihsel olarak sürdüğümüze göre, artık ilk bölümdeki yaygın Platon okuması özetinden hareketle yaygın Platon okumasının bu iki yönle ve bu iki okumayla ilişkisini netleştirebiliriz: Bugünkü yaygın Platon okuması, dogmatik bir okumadır, hatta dogmatik ve gelişimci bir okumadır. Şimdi de yaygın okumanın bu iki niteliğinden hareketle varsayımlarını ortaya çıkaralım.

\section{Yaygın Platon Okumasının Varsayımları}

\section{a. Soyut Rasyonalite Varsayımı}

Yaygın okuma dogmatik ve gelişimci olmasından ileri gelen ne gibi varsayımlara sahiptir? Dogmatik okumaların ortak varsayımı şudur: Felsefe, gerçekliğe uyan bir öğreti (dogma) ortaya koymayı amaçlar, bu nedenle de dramatik öğelerden, dil özelliklerinden, konuşan ve dinleyen kişilerin kimliklerinden ve niyetlerinden temelde bağımsız bir etkinliktir. Bu haliyle dogmatik okuma soyut ya da soyutlanabilir bir rasyonalite anlayışına dayanmaktadır. Buna göre felsefi etkinlik tamamen kavramsaldır, bu nedenle yapıtaşı kavramlardır, organı bildirsel önermelerdir, ürünü de bir tutarlı önermeler bütünüdür.

$\mathrm{Bu}$ soyut rasyonalite varsayımının en azından Platon okuması açısından sorunlu bir yanı, Platon'un neden diyalog yazdığı sorusunu tatmin edici şekilde yanıtlandıramamasıdır. Eğer bütün mesele açık kavramlar, doğru önermeler ve tutarlı öğretilerse Platon neden hayatı boyunca ısrarlı ve istikrarlı bir şekilde diyaloglar yazmış ve yazısının argümantatif yönünü her zaman dramatik yönüyle birlikte içiçe sunmuştur? Platon'un derdi gerçekliğe ilişkin görüşünü ileri sürmekse neden tartışılan konuyu her 
zaman bir takım karakterlerin ağzından yansıtır? Neden Platon diyaloglarında asla kendi ağzıyla konuşmaz, hatta neredeyse görünmez bile? ${ }^{12}$ Konuşturduğu karakterler de neden neredeyse asla tatmin edici bir sonuca varamazlar? Eğer Platon metinlerini doğru önermelere, geçerli çıkarımlara ve tutarlı bir öğretiye güdümlü saymak gerekiyorsa, Platon metinlerinin neredyse kesintisiz sorusallığını ne yapacağız? Eğer Platon metinlerini soyut bir rasyonalitenin ürünü olarak okumak gerekiyorsa, Platon'un metinlerindeki ısrarlı somut rasyonaliteyi nasıl açıklayacağız?

Soyut rasyonalite varsayımının Platon metinleri karşısında düştüğü zorluklar ilineksel de değildir. Tersine, her şey bizzat Platon'un bu metinleri bir soyut rasyonalitenin ilkece başa çıkamayacağı şekilde oluşturduğunu gösteriyor. Dolayısıyla Platon'un metinlerini soyut rasyonalite ile okumanın olanaksızlığı şöyle dursun, bu metinleri soyut rasyonaliteye karşı okumak zorunlu görünüyor. ${ }^{13}$ Russon bu noktayı şöyle dile getirir:

Platon'un metinleri, "felsefe"nin birincil ve özerk olduğunu iddia ettiği soyut "rasyonalite"nin aslında ikincil ve bağımlı olduğunu bize gösterir: onun temelinde yatan ve bağımlı olduğu rasyonalite somut bir rasyonalitedir: tıpkı şiir gibi, ifadesinin biricik ve tikel koşullarından koparılamaz ve, tıpkı sofistlik gibi, bir takım tikel bireyleri ikna etme projesinden ayrılamaz, retorikten arındırılamaz; dolayısıyla bu rasyonalite kopuk bir gözlem tutumuyla çözümleyebileceğimiz türden değildir, bizi kendisine dahil olmaya zorlar. (Russon 2019: 14). ${ }^{14}$

Soyut rasyonalite varsayımının yol açtığı bir başka sorun da Sokrates'in hiçbir şey yazmamasıyla Platon'un diyaloglar yazması arasında hiçbir ilişki kurmaya izin vermemesidir. Hal böyle olunca, etik konularında sonuçsuz ve öğretisiz konuşmalar yapan Sokrates'ten, geometriden teolojiye ve diyalektiğe varıncaya kadar bütün hakikati içeren bir felsefi sistemi oluşturan Platon'a nasıl geçildiği anlaşılmamakta, dolayısıyla Platon’un Sokrates’i geçici bir süre için “vitrin” olarak kullandığı gibi varsayımlar

12 Platon'un adı kendi diyaloglarında üç kez geçer: Sokrates'in Savunması, 34a1, 38b6, ve Phaidon, 59b10. Phaidros 229a-b'deki “çınar" (platanos) da Platon'sa onu da eklemek gerekir.

13 Buradaki soyut rasyonalite eleştirisi ile Sokrates'in mitleri doğa olaylarına indirgeyen "yabani bilgeliğe" (agroikos tini sophia) ayıracak boş vakti olmadığını söylediği Phaidros, 229e pasajı karşılaştırılabilir.

${ }^{14}$ Platon'un felsefi projesi ile Platon okuma deneyiminin başarılı bir temsilini birleştiren bir başka okuma için elbette Schleiermacher 1836: 17-18. Benzer şekilde Sallis 1996: 14-15'e de bakılabilir. 
yapılmak gerekmektedir. Oysa argümantatif öğe ile dramatik öğeyi birlikte düşünme zorunluluğu, Sokrates'in hiçbir şey yazmamasının, hiçbir öğretiye sahip olmadığını iddia etmesinin ve "ebelik" (maieutikê) etkinliğinin Platon'daki karşılıklarını gösterir: Platon da kendi ağzından hiçbir şey yazmayacak, kendi karakterlerini konuşturacak, kendi ağzından bir öğreti ileri sürmek yerine öğretileri karakterlerine anlattıracak, tartıştıracak, böylece Sokrates muhataplarının konuşmasına ebelik yaparken Platon da okurlarını düşünme zorunluluğunun ve işinin tam ortasına bırakacaktır.

Dogmatik okuma, hayatı boyunca diyalog yazmış bir filozofu sanki hep kendi ağzından görüş belirtmiş ve bir felsefi sistem kurmuş gibi ele alır. Bu gibi çarpıtmalar hem mantıksal olarak safsatalıdır, hem okurun kendi varsayımlarını sorgulama alanını hiç açmadıkları için felsefi olmaktan uzaktır, hem de filozofun metinlerini okumayı gereksiz hale getirdiğinden felsefe tarihçiliğine de aykırıdır. Bunların ötesinde bu gibi çarpıtmalar tam da Platon'un bir diyaloğunda Sokrates tarafından sergilenir ve eleştirilir. Theaitetos'ta Sokrates Theaitetos'la bilginin algıyla özdeşleştirilmesinden doğan sorunları tartışırken bu özdeşleştirmeyi Herakleitos'la ve sonra Protagoras'la, hatta Protagoras'ın tek bir sözüyle bağdaştırıp kendince yerle bir eder ama rahat edemez:

Sokrates: Bana öyle geliyor ki tartışmadan [logos] kopmuşuz da adi horoz gibi daha zafer kazanmadan ötüyoruz.

Theaitetos: Nas1l olur?

Sokrates: Öyle bir şey yaptık ki sanki karşı söz üreten adamlar gibi ${ }^{15}$ uzlaşmazlığımızı sözcüklerin uzlaşmasına dayandırarak karşımızdakini sözle bir güzel alt ettik - yani ödül avcısı değil, hikmet aşık1 [philosophos] olduğumuzu söylememize rağmen farkında varmadan o müthiş adamların yaptığ $\breve{s}$ şin aynısını yaptık. ${ }^{16}$

Theaitetos: Ne dediğini daha anlamadım.

Sokrates: Onlar hakkında ne düşündüğümü açık hale getirmeye çalışacağım ben o zaman. Bir şeyi öğrenmiş ve onu hatırlayan kişi o şeyi bilir mi diye sormuştuk; bir şeyi gördükten sonra gözlerini yummuş kişinin o şeyi o anda görmemesine rağmen hatırladığını göstermiştik; ama sonra kişinin o şeyi

\footnotetext{
${ }^{15}$ Antilogikôs: Bu zarf, Protagoras’a atfedilen Antilogikoi Logoi [İtirazlar ya da Sözlere Karşı Sözler] adlı eserin başlığını andırıyor. (Diogenes Laertios, Ünlü Filozofların Yaşamları ve Öğretileri, 3. 37)

${ }^{16}$ Logos sözcüğünün binbir türevinin kullanılmasından dolayı çevrilmesi son derece zor bir pasajdır bu: "antilogikôs eoikamen pros tas tôn onomatôn homologias anomologêsamenoi kai toioutôi tini perigenomenoi tou logou agapan, kai ou phaskontes agônistai alla philosophoi einai lanthanomen tauta ekeinois tois deinois andrasin poiountes."
} 
hatırlamakla birlikte bilmediğini gösterdik - oysa [bir şeyi hatırlayan kişinin o şeyi bildiğini baştan farz ettiğimiz için] bu olanaksızdı. İşte Protagorasçı hikaye böylece tuzla buz oldu, senin bilgiyle algıyı özdeştirmen de onunla birlikte gitti.

Theaitetos: Görünen o.

Sokrates: Ama, arkadaşım, bana kalırsa iki hikayeden ilkinin babası hayatta olsaydı pek böyle olmazdı, kendisini çatır çatır savunurdu. Şu anda o hikaye yetim kalmış, biz de ona çamur atıyoruz. Protagoras'ın geride bıraktı̆̆ 1 vasiler de yetime yardıma gelmiyor - bak işte, Theodoros burda. $\mathrm{O}$ halde adalet namına ona biz yardım edeceğiz gibi görünüyor.

Theodoros: İyi de Sokrates, Protagoras'ınkilerin vasisi ben değilim ki, Hipponikos'un oğlu Kallias... (Platon, Theaitetos, 164c-165a).

Bu pasajı Sokrates'in logos'u bir baba figürüne dayandırması olarak okuyanlar olabilir; ancak, bu okumada vasilerin ve "bizlerin" neden sorumlu olacağ Logos'un öz babası ölmüş olsa da ve hukuki vasileri yardıma yanaşmasa da "yetimin hakkını" verme sorumluluğunun hepimizde olduğunun hatırlatılması olarak bu pasajın okunması ise aynı sakıncalara sahip değildir. İşte Sokrates'in Protagoras'a yaklaşmamamız gerektiğini salık verdiği tutumla Platon'a da yaklaşmaktan kaçınmak gerekir. Bunu yapabilmek için de şimdi yaygın Platon okumasının soyut rasyonalite varsayımının yol açtığı başka varsayımları, silikleştirdiği ya da düpedüz sildiği ayrımları inceleyelim.

\section{b. Söylem Düzeyleriyle İlgili Varsayımlar}

“Platon Konuşuyor” Safsatası: Yaygın okuma, Platon'un diyaloglarındaki bir karakterin görüşlerinin bizzat Platon'un görüşleri olduğunu varsayar. Bu varsayımdaki temel sorun geçersiz bir çıkarım kullanmasıdır: Bir yazarın bir karakterine söylettiği görüşlere bizzat inanıyor ve onları ifade ediyor olması için hiçbir zorunlu neden yoktur, hatta karşıt görüşlere inanması bir o kadar olanaklıdır. Bu varsayımın altında yatan geçersiz çıkarım, bir yükleme ya da izafet hatası (attribution error) sayılmış ve "Platon Konuşuyor" Safsatası diye adlandırılmıştır (Mulhern 1971: 168-172). "Platon Konuşuyor” Safsatası mantıksaldır, dolayısıyla Platon'a özgü bir yanı yoktur. Ancak Platon bağlamında bu safsata ampirik sayılabilecek bir soruna daha yol açmaktadır: 
Platon'un diyaloglarında neredeyse her zaman birçok karakter konuştuğuna ve bu sözler diyalektik ve/ya da elenkhos yöntemi gereği tipik olarak birbirine karşıt olduğuna göre, hangi karakterin görüşlerinin Platon'a atfedilmesi gerektiği konusunda belirsizlik ve keyfilik vardır. Burada "keyfî̀ seçme" (cherry picking) safsatası devreye girer: Platon'a kendi yazdığı karakterin görüşleri izafe edilecekse, bu karakter tam olarak hangi karakter olmalıdır ve neden başka bir karakter değil de o karakter olmalıdır? Daha somut konuşacak olursak, Sofist'te Elealı Yabancı'nın görüşleri, Yasalar'da Atinalı Yabancı'nın görüşleri, Devlet'te ve Protagoras'ta Sokrates'in, Timaios'ta ise Timaios'un görüşleri Platon'a yüklenir. Peki neden? Örneğin, Devlet’te Platon'a Sokrates'in değil Thrasymakhos'un görüşlerinin izafe edildiğini iddia eden Strauss'çu bir yorumcuya ne yanıt verilebilir? Devlet'te Platon'u kardeşleri Glaukon ve Adeimantos'un "temsil ettiğini” iddia eden birine ya da Platon'u Devlet'teki bütün karakterlerin "temsil ettiğini" iddia eden birine karşı ne söylenebilir? "Platon Konuşuyor” safsatası çerçevesinden hiçbir şey söylenemez gibi görünüyor.

Aynı şekilde bir diyalogda bir karakter kendisiyle çeliştiği zaman, fikir değiştirdiği zaman ya da başka bir diyalogda bambaşka görüşler ileri sürdüğü zaman, bunları da mı Platon'a yüklemek gerekir? Fark edilebileceği gibi, eğer Sokratik yöntem ya da diyalektik, bir görüşün ya da algının kendi karşıtıyla karşılaşmasını olanaksız değil zorunlu kıliyorsa, "Platon Konuşuyor" safsatası tam da Platon'un ve/ya da Sokrates'in felsefesinin önünde dikilen bir engel oluşturmaktadır.

“Platon Sokrates’in Ăğzından Konuşuyor” Safsatası: Bu sorular da, makalenin şimdiye kadarki bölümü de, bizi yaygın okumanın bir başka varsayımına getiriyor: Platon'un diyaloglarında Sokrates karakterinin Platon'un görüşlerinin sözcüsü olduğu varsayımı. Fark edilebileceği gibi bu varsayım öncekinin bir alttürüdür, dolayısıyla ilk varsayım safsataysa bu ikinci varsayım haydi haydi safsatadır: Eğer bir karakterin görüşünü yazara atfetmek için hiçbir neden yoksa, Sokrates gibi belli bir karakterin görüşünü yazara atfetmek evleviyetle gerekçeden yoksundur. Nitekim bu varsayımın temelindeki çıkarıma “Platon’un Sözcüsü Safsatası” denir (bkz. Mulhern 1971: 168172). 
Buna itiraz olarak denebilir ki Sokrates Platon'un hocasıdır, dolayısıyla ona duyduğu saygıdan dolayı Sokrates'i kendi sözcüsü yaptığını varsaymamız gayet doğaldır. Ancak burada "doğal” sözcüğü kesin anlamıyla kullanılmamaktadır: Birinin ağzına kendi laflarını koymak kimilerine bir saygı gösterisi olarak görünebilir, ancak başkalarına bir saygısızlık ya da çarpıtma olarak görünebilir - "doğal” olan hangisidir?

Peki Sokrates'in görüşlerini değilse de, sorularını ve soru sorma yöntemini Platon'a yükleyemez miyiz? Burada büyük sorunlar vardır. Öncelikle ilkesel bir sorun vardır: Platon neden kendisi bunları kendi ağzından yazmamıştır? Buna yanıt olarak Platon'un Sokrates'in başına gelenlere karşı önlem almak ve gerektiğinde kendi görüşlerini yadsıyabilmek için Sokrates’i konuşturduğu söylenebilir. Ancak bu da inandırıcı bir gerekçe değildir, zira kendi görüşlerinin başına dert açmasından korkan bir yazarın o görüşleri kendi hocasına söyleterek böyle bir olasılı̆̆ı savuşturmaya kalkması çok güvenilir bir önlem değildir. Bu varsayım Sokrates'in aslında Platon’un görüşlerini dile getirdiğini bizim bugün fark edebileceğimizi kabul ederken, Platon kendi çağdaşlarının aynı görüşleri kendisine yükleyemeyeceğini mi düşünecektir? Kaldı ki Sokrates'in hiç olmadığı diyalogları (örneğin Yasalar'1) ve neredeyse hiç konuşmadı̆̆ diyalogları (örneğin Sofist'i ve Devlet Adamı'nı) ne yapacağız? Benzer şekilde Protagoras'ta Platon'un Sokrates'in tarafinı "tuttuğunu" düşünenler olduğu gibi, Protagoras tarafını tuttuğunu düşünenler de vardır. Hatta Gonzalez ve Russon gibi aynı yaklaşımı paylaşan uzmanlar da bu konuda karşı karşıya gelebilirler (bkz. Gonzalez 2009; Russon 2019: 15).

Son olarak bu varsayım, Platon'a yüklenip yüklenmemeleri bir yana, Sokrates'in bir takım görüşler bildirdiği iddiasındadır. Oysa Sokrates'in bir takım görüşler bildirmesi başlı başına Sokratik olmaktan uzaktır. "Platon Konuşuyor" Safsatası Platon'a ne kadar aykırıysa, "Platon Sokrates'in Ağzından Konuşuyor" Safsatası da Sokrates'e tam olarak o kadar aykırıdır. Zira Platon diyaloglarında Sokrates'in birçok kez söylediği gibi kendisinin bir ögretisi yoktur, olsa olsa bir soru sorma ve/ya da doğurtma (tekhnê maieutikê) tekniği vardır. Sokrates, kendi dediğine göre, hiçbir şey bilmemektedir ki bir görüşü olsun ve biz de bu varsayım altında o görüşü Platon’a 
atfedelim. Ancak Sokrates'in kendi öğretisinin olmadığını defalarca ve gerekçeleriyle söylemesine rağmen, buna kulak asmamayı tercih etmek isteyen yorumcuların elinde bir çare vardır: "Sokratik ironi”ye başvurmak. Böylece Sokrates’in "cehaletinin farkında olma”, elenkhos, ebelik ve benzeri bütün yönleri hiçe sayılıp Platon'un sözcüsü haline getirilebilmektedir. Platon'un yazılmamış sözlü öğretilerine başvuran Platon okumalarının Platon diyaloglarını okumamaya yol açması gibi, istediği zaman Sokrates'in sözlerini ironik olarak yorumlayan birisi artık Sokrates'i dinlemese de olur.

“Sokrates Konuşuyor” Safsatası: Yukarıdaki varsayımları tartışırken ister istemez Sokrates'in ismi geçtiğine göre, yaygın Platon okumasının varsayımları arasında yer almasa da, belki yaygın Sokrates "okumasının" varsayımları arasında anılabilecek bir varsayımdan söz edebiliriz: Platon'un diyaloglarındaki Sokrates'in tarihsel Sokrates olduğu varsayımı, dolayısıyla Platon'un diyaloglarında Sokrates karakterinin söylediklerinin gerçekten yaşamış tarihsel Sokrates'in sözleri olduğu varsayımı. ${ }^{17}$ Benzer bir varsayım Ksenophon değilse bile Aristophanes okumalarında da geçerli olabilir.

İlk olarak bu varsayımın bir önceki varsayımla çeliştiğine dikkat çekelim: Platon diyaloglarındaki Sokrates'in görüşleri, önceki varsayımda ileri sürüldüğü gibi Platon’un kendi görüşleriyse, o zaman aynı görüşler tarihsel Sokrates'in görüşleri olmak zorunda değildir. Ancak bu makalenin başında gördüğümüz gibi, yaygın gelişimci dogmatik Platon okuması bazı diyaloglarda bu varsayımı kullanır, bazılarında ise bir önceki varsayıma el atar: Orta dönem ve geç dönem diyaloglarında Platon'un konuşturduğu Sokrates aslında Platon'un görüşlerinin sözcüsünden ibarettir ("Platon Sokrates'in Ağzından Konuşuyor” Safsatası), ancak Sokratik diyaloglarda Platon’un konuşturduğu Sokrates ise tarihsel Sokrates’tir ("Sokrates Konuşuyor” Safsatası). Dolayısıyla burada bir keyfî seçme vakası daha karşımıza çıkmaktadır.

Daha derinde ise bu varsayımdaki sorunların kaynağının "Platon Konuşuyor" safsatası ve son çözümlemede soyut rasyonalite varsayımı olduğu fark edilecektir:

${ }^{17}$ Dramatik olgularla tarihsel olgular arasındaki düzlem farkı biraz aşağıda tarihlendirme bağlamında gündeme getirilecektir. 
Platon'un metnindeki bir karakterin bulunduğu düzey ile Platon'un kendisinin bulunduğu düzeyi ayırt etmeyen ya da edemeyen birisinin, diyaloglardaki Sokrates'in görüşlerini ya Platon'a ya da tarihsel Sokrates’e yüklemesi doğaldır. Bazı diyaloglarda Sokrates'i Platon'un sözcüsü sayacak, bazı diyaloglarda Sokrates'i tarihsel Sokrates saymayı tercih edecek, ancak neden birinden öbürüne geçtiğini gerekçelendiremeyecektir.

\section{c. Tarihlendirme Ölçütleriyle İlgili Varsayımlar}

Farklı söylem düzeyleri arasındaki sınırlar bulanıklaştıkça, Platon metinlerinin hangi sırayla yazıldığı sorusu en belirleyici ve hatta tek belirleyici soru haline gelir. Buradaki akıl yürütme şöyledir: Eğer karakterlerin görüşleri aslında Platon'un görüşleriyse ve eğer bu görüşler arasında karşıtlık varsa, o halde Platon aynı anda iki karşıt görüşü savunamayacağına göre bu görüşleri farklı dönemlerde savunmuş olmalıdır. Artık geriye o görüşleri Platon'un hangi dönemde savunmuş olabileceğini kavramsal içerikten hareketle tahmin etmek kalmıştır. Oysa Platon metinlerini tarihlendirmede kullanılan ölçütler arasında kavramsal içeriğe başvurmak çok güvenilir bir ölçüt değildir. Bunu görmek için Platon metinlerini tarihlendirme ölçütlerine kısaca bakalım ve onları azalan güvenilirlik derecelerine göre sıralayalım. Görüleceği gibi buradaki eleştirilerin hedefi, artık yaygın okumanın sırf dogmatik olma niteliği değil, gelişimci olma niteliğidir.

Dış Kanıtlar: Bir metin, tarihlerini bağımsız kaynaklardan zaten bildiğimiz tarihsel olay, yer ya da kişilere gönderme yapıyorsa, bu o metnin o tarihten sonra yazılmış olduğu sonucunu çıkarmak için son derece güçlü bir kanıt oluşturur. Söz konusu tarih, metnin yazılış tarihinin terminus post quem'idir, yani alt sınırıdır. Bu ölçüt ve bu kanıt bir metni tarihlendirmede başvurulabilecek en güçlü ölçüt ve kanıttır. Ne de olsa bir metinde Sokrates'in baldıran zehrini içmesinden söz ediliyorsa, o metnin İÖ 399'dan önce yazılmış olabileceğini düşünmek makul şüphenin ötesindedir ve son derece karmaşık komplo teorilerine başvurmayı gerektirir. Benzer şekilde bazı 
adlandırmalar ve ifadeler, kullanıldıkları metnin olsa olsa belli bir tarihten sonra yazılmış olması gerektiği sonucunu çıkarmamıza izin verir. "Hain Alkibiades", “Anaksagoras'ın davası” ve benzeri ifadeler de kullanıldıkları ana ilişkin az çok belli bir alt sınır içerir. Bütün bunlar metni tarihlendirmeye metnin dışından katkıda bulunduğu için "dış ölçütler" diye adlandırılır ve bu listede ilk sırada sayılmalarından da anlaşılabileceği gibi bir metnin tarihlendirilmesinde en güçlü kanıt türünü oluşturur. Bu kanıtlara karşı çıkmak için başvurulacak kanıtların bu kanıtlardan bile daha güçlü olması gerekeceği unutulmamalıdır.

Metinlerarası göndermeler de dış ölçütlerden sayılır. Bir metin, tarihsel bir olaya, yere ya da kişiye göndermek yerine, başka bir metne gönderme yapıyorsa, bu o metinden sonra yazıldığı konusunda kanıt oluşturur denebilir. Ancak bu kanıt öncekiler kadar güvenilir değildir, zira bir metinden öbürüne yapılan gönderme her zaman yeterince açık olmayabilir ya da o metnin gönderme yaptığı metnin tam olarak hangi metin olduğunu belirlemek zor olabilir. Ne de olsa metinlerin başlıkları konusundaki duyarlılıklar ve titizlik dereceleri dönemden döneme göre değişmektedir. Konstantinopolis ve İskenderiye öncesi metinlerde metinlerarası göndermelerin dış ölçüt olarak kullanılması bu nedenle sakınım gerektirir.

Platon'un Devlet'i zaten bu konuda son derece zorlu ve ilginç bir metnidir: Timaios diyaloğunun başında (17b-19b) Sokrates “önceki gün” yaptığı bir konuşmayı özetler; özetlediği konuşma Devlet'te anlatılan konuşma gibidir. Hatta Timaios (27a) Kritias diyaloğunu önceden haber verir gibidir. Kleitophon diyaloğu geleneksel olarak Devlet diyaloğundan önce basılır. Benzer şekilde Theaitetos, Euthyphron, Sofist, Devlet Adamı, Sokrates'in Savunması, Kriton, Phaidon diyalogları bu sirayla birbirlerine referanslar taşırlar. Ancak bir yazarın bir metninin tarihlendirilmesinin "kefili" olarak başka bir metnini kullanmak, metindışı gerçeklikteki tarihsel bir olgu kullanmak kadar sağlam bir yol değildir. En önemlisi, dış kanıtlara başvurulurken tarihlendirme düzlemleri arasındaki farklar hesaba katılmalıdır. Bu düzlemlere bir sonraki altbölümde değineceğiz. 
Stilometrik Testler: Bir yazarın metinlerindeki sözcük dağarcı̆̆ı, benimsenen yazım tercihleri, dilbilgisi kullanımları, edat ve bağlaç şekilleri, ritim ve sözdizimi alanlarındaki örüntülerin istatistiksel olarak haritalanmasından hareketle o metinleri tarihlendirmemizi sağlayan yöntemlere stilometrik testler adını verelim (bkz. Brandwood 1992). Bu yöntemin öncüsü Campbell'dir (Brandwood 1992: 91-94). Campbell stilometrik uygulamasını teknik terminolojinin sayfa başına artışını hesaplayarak Timaios, Yasalar ve Kritias üzerinde yapmış ve bunların önüne Devlet Adamı, Phaidros ve Sofist'i geçirmiştir. Campbell'in bulguları, Dittenberger'in mên edatı üstüne yaptığı çalışmalarla bağımsız olarak desteklenmiştir (bkz. Dittenberger 1881).

$\mathrm{Bu}$ yöntemin öbürlerinden bir farkı, açıkça teknolojiye dayanmasıdır. Dolayısıyla gelecekte bu ölçütün ağırlık kazanbileceği düşünülebilir. Nitekim günümüzde internette "arama motoru” kavramıyla içli dışlı olmamız sayesinde, bir yazarın bütün yazılarında "gerçekten", "gerçekte”, “aslında", "esasında", "filhakika", "hakikaten", "hakkaten" ve az çok eşanlamlı deyimerlin sıklıklarının ne kadar kolayca hesaplanıp haritalanabileceğini hayal etmekte zorlanmayı. Yani bir gazete, günlük ya da ders kitabı yazarının metinlerinin tarihlendirilmesinde belki stilometrik testler başarılı olabilir. Ancak eski dil şekillerini (arkaizmleri), zamandizini bozan şekilleri (anakronizmleri) ve bu gibi dilsel oyunları kasıtlı olarak kullanabilen yazarlarda, en azından belki tiyatro yazarlarında ve tabii pastişçilerde, stilometrik testler test eden taraf olmaktan çıkıp test edilen taraf haline gelebilir. Nitekim, belli yazarların eserlerini tarihlendirmede bağımsız kanıtların desteklemesinden anlaşıldığı kadarıyla başarılı olduğu sonucuna varılan bu stilometrik yöntemler, James Joyce'un Ulysses'inin 5 ayrı yazar (hatta Sanatçının Bir Genç Adam Olarak Portresi'nin yazarından farklı olan 5 ayrı yazar!) tarafından yazılmış olduğu sonucunu vermektedir (Schoenbaum 1996: 196). Platon'un metinlerini tanıyan okur bu metinlerin bir gazete haberinden çok Joyce'un metinleriyle aynı muameleyi gerektireceğinden şüphe etmez.

Kavramsal Içerik: Yaygın Platon okuması temelde diyalogların tarihlendirilmesine dayanır ve bu tarihlendirmede diyalogda dile getirilen "öğreti”yi 
esas alır, yani kavramsal içeriğe bel bağlar. Felsefi ve siyasi metinlerde geçen konular, sorunlar, yöntemler, kuramlar ve etkiler, bu metinlerin ne zaman yazıldığına ilişkin kanıtlar olarak kullanılabilir. Ancak bu tür kanıtların önceki ölçütlerden daha da bulanık olduğunu görmek zor değildir. Zira bu kanıtın kullanılması sıklıkla yazarlık konusunda kariktürü andıran bir görüşün benimsenmesini gerektirir: Bir yazar aynı zamanda ancak ve ancak tek bir öğretiyi (ya da yöntemi, konuyu, soruyu, etkiyi) kullanır, sonra da kullanmaz. Ancak buradaki çıkarım son derece zayıftır. Nitekim "ruh göçü” öğretisi, "bölme" (diairesis) yöntemi, aşk konusu, erdemin öğretilebilip öğretilememesi sorusu ya da Elealıların etkisi birden fazla diyalogda karşımıza çıkar, ancak bu durum o diyalogların aynı dönemde yazıldı̆̆ı sonucunu çıkarmamız için yeterli değildir. Benzer şekilde farklı konuları işleyen, farklı yöntemler kullanan, farklı sorunlar doğuran ya da farklı etkiler taşıyan diyalogların farklı dönemde yazıldıkları çıkarımı zorunluluk taşımaz.

Yazınsal Ölçütler: Üslup, ustalık, sanatsal nitelik, dramatik hakimiyet gibi tarihlendirme ölçütleri herhalde olabilecek en zayıf ölçütlerdir. Bu ölçütleri zayıf kılan önemli bir etken, önceki ölçüt olan kavramsal içeriği zayıf kılan etkenle aynıdır: son derece kaba bir "yazar” klişesine dayanırlar. Bu klişeye göre, bir yandan yazar “ustalaşır”, yazarın üslubu "incelir", yazarın yazarlığı zaman içinde "iyileşir”, öbür yandan da bu "ustalık", "incelik" ya da "iyilik" gibi kavramlar nesnelleştirilebilir ve ölçülerek diyalogları tarihlendirmemize temel oluşturabilir. Oysa bu iki fikir de sorgulanmaya gayet açıtır.

Tarihlendirme ölçütlerimizi toparlayacak olursak, Platon'un diyaloglarını tarihlendirmede dış kanıtlar açık farkla en güçlü ölçütü oluşturur: hem mutlak olarak bir dış kanıtı çürütmek zordur, hem de görece olarak bir diş kanıtı çürütecek başka bir kanıt bulmak zordur. Ancak diş kanıta bel bağlamanın sorunlu bir yanı, bir metnin yazılış tarihini belirlemek için başvurduğumuz metindışı olgunun tarihinin neye göre belirlendiği sorusunun yanıtlanmasının zorluğu olabilir. Platon'un Devlet'ini tarihlendirmek için bir dış kanıt olarak Devlet'te 368a'da sözü geçen bir Megara Savaşı'na bel bağlayabiliriz, ancak Megara Savaşı'nı tarihlendirmek için neye bel 
bağlacağız? 424 tarihini veren Thoukydides'e (4.72) mi, 409 tarihini veren Sicilyalı Diodoros (13.65) mu, yoksa 456 tarihini veren Benjamin Jowett mı? Son olarak, insan, olay ya da yer isimleri gibi $d$ lş kanıt olduğu izlenimi veren sözcüklerde bile yanılma payı vardır. Platon'un Parmenides'inde genç bir karakter vardır, adı Aristoteles'tir, oysa bizim tanıdı̆̆ımız Aristoteles değildir. Metinlerarası göndermelerdeki belirsizlik payı da bundan kaynaklanır.

Sonuç olarak yaygın Platon okuması dogmatik ve gelişimci bir okuma olduğuna göre ve gelişimci dogmatik okuma Platon diyaloglarının tarihlendirilmesini kavramsal içeriklerine ve yer yer stilometriye dayandırdığına göre (Tigerstedt 1977: 25), kavramsal içeriğin ve stilometrik testlerin tarihlendirmede en güçlü ölçütlerden olmaması yaygın Platon okumasının güvenilirliğini azaltmaktadır.

\section{d. Tarihlendirme Düzlemleriyle İlgili Varsayımlar}

Söylem düzeylerini ve metin tarihlendirme ölçütlerini ayrıştırdıktan sonra, bu ölçütlerin kullanılacağı metin tarihlendirmelerinin üç farklı türünü ya da düzlemini ayrıştırmak gerekir. Yaygın Platon okuması bu farkları da silikleştirebilmekte ve birinden öbürüne gerekçesiz şekilde geçebilmektedir.

Yazılış Tarihi: Devlet diyaloğunu alalım. ${ }^{18}$ Diyaloğu Platon'un yazdığı tarih, elbette bu diyaloğun yazılış tarihidir. Örneğin Guthrie Platon'un Devlet'i yazmayı 374’te bitirdiği görüşündedir (Guthrie 1975: 437). Bu kadar basit görünen bir iddia bile yakından bakıldığında birçok sorun baş gösterir. Öncelikle Devlet'in yazılmasının 374 'te bitmesi o y1l yazıldığı anlamına gelmez. Nitekim Devlet'in ilk kitabı belki ayrı bir diyalog oluşturuyordu, hatta Thrasymakhos başlığını taşıyordu ve Platon'un bir gençlik eseriydi. Ayrıca birçok uzman Platon'un Devlet'i yaşlılığında bile revize ettiği görüşündedir (bkz. Nails 1998). Sonuç olarak bir eserin bittiği tarihle yazıldiğı tarihi, hatta "oluşturulduğu" ya da "tasarlandığı" tarihi ayırt etmekte yarar vardır. Marcel

18 Burada yaygın okumanın farklı tarihlendirmeleri örtüştürmesini örneklendirmeyi ve bunların ayrıştırılması gereğini göstermeyi amaçladığımızdan, Devlet diyaloğunun dramatik tarihiyle ilgili sorunlar için Nails 1998'e gönderme yapmakla yetinelim. 
Proust'un Kayıp Zamanın İzinde eseri bu gibi ayrımların ne kadar önemli olduğunu kolaylıkla görebileceğimiz eserlerdir. İşte yaygın okumaya mesafe koyulabilirse Platon'un eserlerinin böyle eserler olduğu ve aynı "edebi” titizlikle okunması gerektiği fark edilebilecektir.

Öyküdeki Olayın Tarihi (Dramatik Tarih): Metnin yazımıla ilgili karmaşıklıkları bir yana bırakıp Platon'un Devlet diyaloğunu 374 yılının içerisinden baştan sona yazdığını kabul edelim. Metnin yazılış tarihinden neredeyse tamamen farklı bir "tarih" daha vardır, bu da tabii ki metinde anlatılan "olayın" geçtiği tarihtir, yani metnin dramatik tarihidir: Devlet' in yazılış tarihi İÖ 374 olsa da, dramatik tarihi İÖ 411 olabilir: Örneğin metin yazıldığı sırada Devlet’te karakterlerin çoğu çoktan ölmüş olsa da, metinde anlatılan olayda hepsi tabii ki hayattadır.

Aslında burada bile Devlet ek bir karmaşıklık düzeyi barındırır: Devlet aslında bir diyalog değil de, bir diyaloğun sonraki gün Sokrates tarafından başkalarına aktarılması olduğu için, Devlet'in dramatik tarihi aslında Sokrates'in Glaukon'la ve diğerleriyle konuştuğu günden bir gün sonradır. Bu yeni söylemsel karmaşıklık düzeyleri kesinlikle Devlet'e özgü değildir. Hatta Theaitetos ve Phaidros gibi diyaloglarda yeni söylemsel karmaşıklık düzeyleri hem kullanılmakta, hem de dile getirilip tartışılmaktadır.

Olgunun Tarihi: Bir üçüncü tarihlendirme düzleminin devreye girdiği de olur. 374 yılında yazılan bir metinde olay 411'de geçiyor olabilir, ancak bazı durumlarda olayın dramatik tarihi ile tarihsel olarak gerçekleştiği tarih örtüşmeyebilir, çünkü bir yazar 374 yılında yazdığı bir metinde tarihsel olarak 420'de olmuş bir olayı 411'de geçiyormuş gibi canlandırabilir. Bu durumda yazılış tarihi olan 374 ve olayın canlandırıldığı dramatik tarih olan 411'den farklı olarak, 420 olayın tarihte gerçekleştiği tarihtir. Platon'un Devlet'te Kephalos'u 411'de dramatik olarak canlandirıyor diye Kephalos'un tarihsel olarak 411'de hayatta olması gerekmez.

Makalemizi bu noktada toparlayacak olursak, önceki bölümlerde yaygın Platon okumasını özetleyip Platon metinlerinin yapısı ve alımlama tarihinden hareketle nitelendirdikten sonra, bu bölümde bu yaygın okumanın varsayımlarını ortaya çıkardık 
ve onların zorunlu olmadığını göstermeye çalıştık: Önce yaygın Platon okumasındaki soyut rasyonalite varsayımını eleştirdik, yani yaygın okumanın argümantatif öğenin dramatik öğeden bağımsız olarak ele alınabileceği varsayımına karşı çıktık. Sonra üç söylem düzeyinden, Platon'un, diyaloglardaki karakterlerin (özellikle Sokrates'in) ve tarihsel Sokrates'in görüşleri arasındaki kaymaların geçersiz ve gerekçesiz olduğunu savunduk; dört tarihlendirme ölçütü arasından, yaygın okumanın inandırıcılığını emanet ettiği "kavramsal içerik" ve "stilometri” ölçütlerinin görece zayıf ölçütler olduğunu ileri sürdük; son olarak yaygın okumanın üç tarihlendirme düzlemini ayırt etmekte özensiz davrandığını, oysa Platon'un böyle bir ayrıştırmayı gerektiren ve teşvik eden bir yazar olduğunu savunduk.

\section{Platon Diyaloglarında Diyalog Şekliyle İlgili Pasajlar}

Sonuç olarak bu makalede Platon okurlarının Platon metinlerinin dramatik yönünü, yani Platon'un ısrarla diyalog şeklinde yazmış olmasını ihmal etmemesi gerektiğini savunuyoruz. Yaygın Platon okumasına eleştirimizin merkezinde de Platon'un bu kadar ısrarlı ve sürekli olarak kullandığı diyalog şeklini hesaba katmaması vardır. Peki Platon'un metinlerinin neredeyse hepsi diyalog olsa da, Platon'un diyalog şekline özellikle duyarlı olduğunu nerden biliyoruz? Alt tarafı gençliğinden beri alışık olduğu tiyatro şeklini kullandığı ve bunu göz ardı etmekte dogmatik okumanın haklı olduğu fikrine ne yanıt verebiliriz?

$\mathrm{Bu}$ gibi itirazlara yanıt verirken bizim "Platon Konuşuyor" safsatasına düşmememiz gerektiği açıktır. Yani Platon'un diyaloglarında karakterlerin dile getirdiği bir takım önermelerden Platon'un görüşleriymiş gibi yararlanamayız. Peki bu durumda ne yapabiliriz? Platon'un her zaman kullandığı diyalog şeklini okurun da her zaman hesaba katmasını istediğini düşündüren birkaç gösterge vardır. Platon kendi ağzından konuşmadığı için ve karakterlerinin görüşleri de ona atfedilemeyeceği için, bu göstergeler için "Platonik jestler" adını verebiliriz. ${ }^{19}$ Platonik bir jest, bir Platon

\footnotetext{
${ }^{19}$ Platonik jest fikrine son derece yakın fikirler için $b k z$. Schleiermacher 1836: 17-18.
} 
diyaloğunda Platon'un dramatik yönün argümantatif yöne ya da argümantatif yönün dramatik yöne müdahale etmesini sağladığı bir durumdur. Bu anlamda Platonik jestler performatiftir. Basit bir örnekle anlatacak olursak, Devlet gibi bir diyalogda haklılık/haksızlık hakkında konuşan bir karakterin başka bir karaktere haksızlık etmesi ya da konunun hakkını vermemesi Platonik bir jesttir. Böyle bir jest hem haklılık/adalet tartışmasının konuşmacılardan kopuk ve soyut bir düzlemde yürütülemeyeceğine işaret eder, zira haklılık konusunda bir görüş bildirmek ya da tartışma yapmanın bile bir tür "hak" ya da "adalet" anlayışını önceden gerektirdiğine "işaret” eder; hem de okuru tartışmanın kavramsal ve soyut içeriğinin ötesine ya da berisine firlatır: okuru kendi okuma, düşünme ve soru sorma etkinliğine geri iter.

Yaygın okumanın örtüştürdüğü ve birbirine bulandırdığı öğeleri önceki bölümde ayrıştırmamız sayesinde bu öğeler arasındaki temas anlarını ve hatta temas türlerini okur artık fark edebilir: Sokrates karakterini tarihsel Sokrates'ten, Sokrates karakterini Platon'dan, dramatik yönü argümantatif yönden, dramatik tarihlendirmeyi dışsal kanıtlardan ve kavramsal içerikten artık ayırt edebiliriz, hem de bunu ayırt edilen taraflardan birini öbürüne indirgemeden ya da yoksaymadan yapabilecek durumdayiz. Birkaç Platonik jest türü hayal edebiliriz; dramatik yönün argümantatif yöne müdahalesi türlü türlü olabilir: elbette doğrulayıcı olabilir (örneğin cesareti atılganlığa indirgeyen bir karakter öbür karakterlere saldırgan davranır ya da tartışmaya azimle bağlanır), yanlışlayıcı olabilir (örneğin dostluğu savunan birisi başka bir karaktere hasmane davranır ya da tarihsel olarak ona düşmandır)... Ancak Platonik jestler tipik olarak bunlardan daha karmaşıktır: düzeyler arasında doğrulama ya da yanlışlamadan çok, paradoks oluştururlar ve/ya da kendine gönderim yaparlar. Platonik jest, dünya ile düşünce arasında ani bir ilişki kurar, böylece ikisinin ayrı düzlemler olduğu varsayımını askıya alır, bu açıdan Brecht' in “yabancılaştırma efekti”ni andırır. Bir Platonik jestin ne anlama geldiği konusu belirsizdir, çünkü dediğimiz gibi bu jest ne Platon'un ne de bir karakterin önermesidir, ne de bir eylemdir. Platonik jest Austin'in “dil edimi” kavramını da akla getirebilir: gerçekten de Platonik jestte önplanda bir karakter bir karaktere bir şey yapar ama arkaplanda Platon okura bir şey yapar - onu bir paradoksla, bir 
çelişkiyle, adeta bir Koan'la karşı karşıya bırakır²0; Sokrates'in Atina'yı at sineği gibi sokmasına benzer şekilde Platon bu jestlerle okurunu dürter (Sokrates'in Savunması, 30 ).

Platon'un diyaloglarına döndüğümüzde, Platon'un okurun diyalog şekline dikkat etmesini istediğine yönelik en azından birkaç güçlü Platonik jest bulabiliriz. Şimdi yaygın Platon okumasının metinlerin dramatik yönünü ihmal etmesinin önemli bir handikap olduğu yönündeki eleştirmizi üç pasajla destekleyelim.

\section{a. Protagoras'ta Diyalog: Nutuk mu, Öykü mü, Diyalog mu?}

Protagoras'ta diyalog pratikte sergilenirken teorik olarak ara ara tartış1lır da. Bazen konu dağılır ama bazen de konuşmanın kendisi dağılır. Bu yüzden diyalog bir konu hakkında konuşma kadar konuşma hakkında konuşmayı da gerektirir. Bu konuşmalardan birinde Protagoras karakteri öykü anlatmayı nutuk çekmeye (logos) tercih ettiğini, çünkü öykünün dinleyicinin daha çok hoşuna gittiğini söyler. (320b-c) Sokrates ise biraz ileride felsefi tartışmaya en uygun şeklin diyalog olduğunu söylerken farklı bir gerekçe sunar: sorulu yanıtlı diyalog dinleyicinin her an soru sorabilmesine izin verir ve konuşmacının uzun uzun laflarla tartışmayı bulandırmasına engel olur. (328e-329b) İşte diyalog şekli bu nedenle tercih edilmiş olabilir: Felsefi tartışmada konuşan kişinin karşısındakine karşı sürekli sorumlu olması gerekir; risale, şiir ya da nutuk gibi başka şekillere oranla, sorulu yanıtlı diyalogda konuşan kişi bu sorumluluğa en çok sahiptir; dolayısıyla diyalog, felsefi tartışma için en uygun şekildir. Sokrates'in bunu savunması doğaldır, zira kendisi bunu uygular, konuşurken ya da soru sorarken her adımda karşısındakinin onayını ister ya da fikrini sorar. Ancak Sokrates'in diyaloğu

\footnotetext{
${ }^{20}$ İnsanı epistemik olarak bir üst düzeye "firlatan" ya da "çağıran" şeyin çelişki olduğunu Sokrates'in ağzından duyarız (Devlet, 523a-c). Aslında Parmenides'teki simetrik "birdir" ve "bir değildir" alıştırmalarının amacı da genç Sokrates'i diyalektiğe 1sındırmaktır; nitekim Sokratik çürütme de temelde çelişkiye vardırma ve o sayede epistemik ilerleme sağlama tekniğine dayanır. Yani Menon'da (82e-84d) kölenin kendi yanıtının bizi vardırdığı çelişkili sonuçları fark etmesi de Devlet'te ya da Theaitetos'taki algısal paradokslar da Sokrates'in muhatabına düzey atlatmaya (hayal gücü ve belleğinin ötesinde aklını kullanmaya) yönelik teşviklerdir; Platonik jestte bu teşvik Sokrates’ten muhatabına doğru değil, Platon'dan okura doğru gerçekleşir.
} 
tercih etmesinden hareketle Platon'un diyaloğu tercih etmesiyle ilgili sonuç çıkaramayız. Protagoras diyaloğuna yerleştirdiği bu Platonik jestle Platon aslında kendisinin okurla ilişkisine işaret etmektedir: diyalog Sokrates'in muhatabının Sokrates'i her an takip etmesini ve ona her an karşı çıkabilmesini sağladığ gibi, Platon'un okuru olan bizlere de her an metni indirip Sokrates'le ya da bir başkasıyla tartışabilmemizi sağlar, kafamızın rahat rahat karışmasına ve o karışıklığ yaşayabilmemize ve aşmaya çalışmamıza izin verir. Görüldüğü gibi Sokrates karakterinin muhataplarında yaratmayı amaçladığı şeyle Platon'un okurunda uyandırmak istediği etki aynıdır: cehalet farkındalığı, cehaletle barışma.

Ancak Protagoras diyaloğunun sonu, hem pratik uygulamada hem teorik tartışmada sorulu yanıtlı diyalog şeklinin felsefi tartışmanın dağılmayıp ilerlemesi için yeterli olmadığını gösterir (360e-361d). ${ }^{21}$ Dolayısıyla Protagoras diyaloğu yalnızca erdemin özellikleri konusunda değil, felsefi tartışmanın şekli konusunda da aporetiktir, sonuçsuzdur: diyalog şekli, başka şekillere oranla felsefi tartışma için daha uygun olabilir, ancak yine de yetersizdir.

\section{b. Theaitetos'te Diyalog: Arasözlü Diyalog mu, Arasözsüz Diyalog mu?}

Diyalog şeklinin açıkça gündeme getirildiği ve böylece yaygın Platon okumasına gölge düşüren ikinci bir diyalog da Theaitetos'tur. Bu diyaloğun başında Eukleides yıllar önce Sokrates'in kendisine anlattı̆̆ bir diyaloğun notlarını Terspion'la paylaşacakken şöyle der:

Konuşmayı Sokrates'in bana anlattığı şekilde anlatarak [diêgoumenon] yazmadım da, kendisinin sohbet ettiğini söylediği kişilerle karşılıklı konuşmasını yazdım. (...) Konuşma aralarındaki anlatıların yazının akıcılığını bozmaması için Sokrates konuştuğunda "ben de dedim ki" ya da "diye belirttim" ya da muhatabı için "kabul etti" ya da "onaylamadı" gibi lafları attım ve Sokrates'in muhataplarıyla konuşmasını bire bir yazıya döktüm (Theaitetos, 143b-c).

\footnotetext{
${ }^{21}$ Ayrica bkz. Pettersson 2017.
} 
Protagoras öyküyü nutka tercih ederken dinleyicinin zevkini gözettiği gibi, burada da Eukleides akıcılığından dolayı taklidi (mimêsis) anlatıma (diêgêsis) tercih eder. ${ }^{22}$

Platon'un diyaloglarında diyalog şeklinin kendisinin tartışıldığı son pasaja geçmeden önce, yaygın okumanın Theaitetos'u okumada özellikle özensiz davrandığını ekleyebiliriz. Eukleides'in üslupla ilgili bir sözü Platon'un üslupla ilgili bir görüşünün ifadesi sayılmakta, hatta Platon'un üslup konusunda hayatının sonuna kadar uyacağı bir taahhüde dönüştürülmektedir. Gene Theaitetos'ta Platon'un "bilgi” ya da "bilim” tanımını verdiği ve hatta binyıllarca bu tanımın geçerli kaldığı da düşünülebilmektedir. Oysa ki Theaitetos yaygın Platon okumasının varsayımlarını altüst eden içiçe söylemsel çerçeveler kullanır, metnin bölümleri arasında ve hatta metinle başka metinler (Sofist, Devlet Adamı ve Euthyphron) arasında dramatik bağlar kurar.

\section{c. Devlet’te Diyalog: Diyalogda Diyaloğa Reddiye}

Önceki pasajlardan farklı olarak Devlet'in III. kitabında diyalog şekli ayrıntılandırılır ve, en önemlisi, reddedilir. Eğitimde kullanılacak metinlerde nelerin söyleneceğini belirledikten sonra Sokrates, bunların nasıl söyleneceklerini tartışmaya başlar ve bunun için Theaitetos'taki terimleri kullanarak üçlü bir ayrım yapar: basit anlatma (diêgêsis), taklit ya da canlandırma (mimêsis), bir de bu ikisinin karışımı. (Devlet, III, 392c-d). Ayrımı anlamayan Adeimantos'a açıklamalar ve örneklerin ardından Sokrates "bekçilere” taklit yoluyla, yani tam da Platon'un kullandığ şekliyle söz söylenmemesi gerektiğini söyler. İki gerekçesi vardır: Hem aynı kişi bu üç farklı söz türünün hakkını veremez, hem de insanın taklit ettiği şey zamanla onun "ikinci doğası" haline geldiğinden (395c-d) bekçiler illa taklit edeceklerse iyi davranışları taklit etmelidir, kötü davranışları yansıtacaksa onları taklit etmemeli, onları

$22 \mathrm{Bu}$ pasajdan hareketle Brandwood "ben dedim, o dedi" tarzı arasözlerin bulunduğu diyalogların Theaitetos'tan sonra yazılmış olması gerektiğini iddia eder. (Brandwood 1992: 90.) Ancak burada da "Platon Konuşuyor" Safsatası vardır: arasözleri rahatsız edici bulan kişi Eukleides karakteridir, Platon değil. Kaldı ki bunları söyleyen Platon olsa bile, arasözlerin bulunduğu diyalogları bu sözden sonraya tarihlendirmek için yeterli bir kanıt mıdır bu? Bir dilsel tercihin tek belirleyicisi akıcılık mıdır? İlginçtir, birçok yazara göre Platon'un "yaşlılık dönemine” tarihlendirdikleri yaşlılık üslubu (örneğin Sofist'in, Timaios'un ve Yasalar’ın üslubu) tam da akıcılıktan uzaktır (Nails 1998: 393). 
anlatarak aktarmakla yetinmelidir. (396d) Okurun da fark edebileceği gibi, bunlar doğrudan doğruya taklide yönelik eleştiriler değildir; taklit henüz kendince kötü ya da sakıncalı değildir. Taklide yönelik asıl eleştiri taklit edecek kişinin kllıktan kılı̆̆a girmesinden, binbir türlü sesi yeniden üretmesinden ileri gelir:

"İkisinden birinde [yani iki "söyleme" tarzı ya da şekli olan "anlatım" ve "taklit”"ten ilki olan "anlatım"da] az değişmeler olur; insan söylemesine uygun makam ve ritim de katarsa, iyi söyliyenin hemen hemen hep ayn makama göre ve değişmeler ufak olduğu için hep tek bir makamda ve ona uygun bir ritimde söylemesi mümkündür."

"Şüphesiz, öyledir" dedi.

"Peki, ama ötekinin [yani taklidin] söyleme şekli tam aksine, kendine has ifadeyi bulmak için makamların, ritimlerin hepsine ihtiyacı vardır çünkü onda değişmelerin her türlüsü bulunur."

"Çok doğru."

"O halde, şairlerin, söz söyliyen insanların hepsi bu anlatma tarzlarının ya birini, ya ötekini, yahut da ikisinden katışı bir tarzı kullanırlar, değil mi?"

"Öyle olsa gerek" dedi.

"Peki, ne yapacağız, dedim, bütün bu tarzları devletimize alacak mıyı?

Yoksa basit tarzların yalnız birini mi, veya katışı tarzı $\mathrm{m}$, hangisini alacağı??"

"Benim fikrim üstün gelirse ${ }^{23}$, dedi, uslu akıllı adamı taklid eden ve katışık olmıyan anlatma ${ }^{24}$ tarzını alırız."

"Ama katışık tarz da tatıdır, Adeimantos, çocukların, lâlaların ve çoğu insanların en çok hoşuna giden tarz, senin seçtiğinin karşıtıdır."

"Hoştur da ondan."

"Ama belki bizim devlete uymaz, diyeceksin [phaiês], çünkü bizde her insan bir iş gördügüü için iki veya bir çok taraflı olamaz."

"Evet, uymaz devletimize."

"Bunun için değil midir ki, yalnız böyle bir şehirde kunduracı kunduracıdır, kunduracılığından başka bir de dümencilik etmez, çiftçi çiftçidir, çiftçilikten başka bir de hâkimlik etmez, asker askerdir, askerlikten başka ticaretle uğraşmaz, hepsi de aynen öyledir."

"Doğru" dedi.

"Öyleyse, belli ki her kılığa girmesini, her şeyi taklid etmesini ustalıkla bilen bir adam şehrimize gelip de şiirlerini temsil etmek isteseydi, şaşılacak, hoş, kutsal bir varlık gibi önünde secde ederdik [proskynoimen], fakat şehrimizde

23 "Üstün gelme" ifadesi doğrudan Eski Yunanca metinde vardır ve Rohde gözetimindeki Erhat 1944 çevirisinde görünmektedir - bununla birlikte öznesi "fikir" olmayabilir. Demirhan 2007 de, uyarlanmış Erhat 1998 baskısı da, Eyüboğlu \& Cimcoz 2006 çevirisi de burada metinden uzaklaşırlar.

${ }^{24}$ Erhat 1944'te, Azra Erhat herhalde buradaki dişil tanımlığın diêgêsis'ten geldiğini düşündüğü için böyle çeviriyor, oysa dişil cins 397c7'deki leksis'ten kaynaklanmaktadır. Zaten şu haliyle çeviri metin, taklit eden bir anlatma olduğunu düşündürüyor, oysa anlatma (diêgêsis) ve taklit (mimêsis) aslında söylemenin (leksis) iki ayrı türüdür. Dolayısıyla burada "anlatma" yerine "söyleme" demek gerekir. Demirhan 2007 çevirisine de bakılabilir. Aynı sorun Eyüboğlu \& Cimcoz 2006' ya da bulaşmışa benziyor. Bu pasajın tamamı Türkçe'deki Devlet çevirilerini karşılaştırmak için iyi bir "sondaj” metni oluşturabilir. 
onun gibi adam bulunmadığını, bulunmasının da yasak olduğunu söyler, başına kokular sürdükten, yün şeritlerden bir taç koyduktan sonra, onu başka bir şehire gönderirdik. Biz ise selâmetimiz için daha sert, daha az hoş bir şairi, bir hikâyeciyi dinleriz. O bizim için yalnız aklı başında adamın söyleyişini taklid etsin, sözlerini, askerlerimizin terbiyesini ele aldığımız zaman kanun olarak koyduğumuz şekillere uydursun."

"Evet, dedi, elimizde olsaydı, öyle yapardık." (Devlet, III, 397b-398b; Azra Erhat çevirisi / 1944).

$\mathrm{Bu}$ ayrıma ve "yasaya" göre, Platon'un diyalogları yalnızca iyi adamı taklit etmeyip binbir türlü karakteri taklit ettikleri için, herhalde Platon'u da çelenkler takılmış, kokular sürünmüş şairlerle birlikte ideal devletten sınırdışı etmek gerekecektir. Zira hiçbir diyalogda gerek anlatıcı kimliğiyle gerek bir karakter olarak Platon kendi konuşmaz, her zaman taklit edilen bir karakterin sesini duyarız. ${ }^{25}$ Buradaki tuhaf "otosansür", daha doğrusu argümantatif düzeydeki yasağın dramatik düzeye uygulanması ve onu ortadan kaldırması gereği iyi bir Platonik jest örneğidir.

$\mathrm{Bu}$ bölümden çıkaracağımız sonuç, Platon'un hayatı boyunca neredeyse her zaman ve neredeyse yalnızca diyaloglar yazmasının ötesinde, diyalogların kendisinde Platon'un diyalog şekline son derece duyarlı olduğuna yönelik apaçık göstergeler saptanabildiğidir.

\section{Sonuç Yerine}

Sözü bağlarken bu makalede ne yaptığımızı kısaca hatırlayalım. Yaygın Platon okumasının anahatlarını çizdikten sonra, onu Platon metinlerinin özel yapısı ve Platon alımlama tarihi açılarından "gelişimci dogmatik" bir okuma olarak nitelendirdik ve bundan hareketle varsayımlarını ortaya çıkarıp eleştirmeye çalıştık; Platon diyaloglarında diyalog şeklinin bir kenara bırakılamayacağına ilişkin göstergelere de işaret ettiğimize göre, artık bütüncül iddiamızı dile getirebiliriz: Platon'un bu kadar

${ }^{25} \mathrm{Bu}$ elbette taklit edilen bu karakterlerden birinin taklitlerine ve anlatımlarına diyaloglarda yer verilmediği anlamına gelmez. Örneğin Devlet'te Platon ikinci şekli kullanarak Sokrates'i konuşturur, ona önceki gün yaptığı bir konuşmayı anlattııır; Sokrates de o konuşmayı üçüncü şekli kullanarak aktarır. Nitekim Devlet'te arasözler vardır. 
sürekli ve bilinçli olarak kullandiğı diyalog şeklini hesaba katmayan hiçbir Platon okumasi geçerli sayılamaz.

$\mathrm{Bu}$ sonuç, en azından üç yeni çalışmanın gerekliliğine de işaret etmektedir.

Öncelikle Platon metinlerinin nasıl okunmaması gerektiğiyle ilgili bu tartışmanın arkasından, burada eleştirilen varsayımlara dayanmadan Platon metinlerinin nasıl okunması gerektiği tartışılmalıdır. Bu çerçevede örneğin "Platonik jest" kavramı irdelenmeli, dramatik yön ile argümantatif yön arasındaki bağlantılar sınıflandırılmalı ve farklı tarihlendirme düzeylerindeki ilişkiler belirlenmelidir. $\mathrm{Bu}$ çalışmayı yönlendiren soru şudur: Bu makalede dogmatik okumayı eleştirdikten sonra, Platon'a hiçbir öğreti, hiçbir sistematik araştırma, hiçbir gelişme atfedemeyecek miyiz? Böylece yeniden kuşkucu okumaya savrulmuş olmuyor muyuz? Belli ki dogmatik okumadan da kuşkucu okumadan da ayrı bir okuma önermek gerekecektir. Bu okumanın sınırları, ilkeleri, öbür okumalarla ilişkileri ve en önemlisi de yöntemi tartışılmalıdır.

Nitekim ikinci olarak da bu teorik tartışmalar Platon'un diyalogları üzerinde uygulanmalıdır, açıklama güçleri ve yorumlama olanakları yaygın okumanınkilerle karşılaştırılmalıdır. Burada Yeni-Platonculuğun ve başka okumaların düştüğü hatalardan biri olan seçiciliğe düşmemek için ne gibi önlemler alınması gerektiği tartışılmalıdır. Örneğin yaygın okumanın birbirinden ayırdığı metinleri ayırmadan ve bağladığı metinleri bă̆lamadan işe başlamakta yarar olabilir.

Son olarak da yaygın Platon okumasının eleştirisinin sonuçları hem SokratesPlaton ilişskisi hem Platon-Aristoteles ilişkisi bağlamında çıkarılmalıdır. Eğer yaygın Platon okuması terk edilecekse bu Platon'un öncel ve ardıllarıyla ilişkisini değerlendirmemize nasıl yansıyacaktır? Örneğin dogmatik Platon okumalarının Aristoteles'in felsefi kariyerini de belirledikleri düşünülebilir: buna göre Akademi'de Platoncu öğretilerle yetişen Aristoteles sonradan hocasına sırt çevirmiştir... Bu görüş Akademi'deki eğitimin dogmatik olduğunu varsaymaktadır. Oysa Carlo Natali’nin Aristoteles'in Akademi'deki yıllarını anlatırken dediği gibi: "Büyük olasılıkla [Akademi'de] hocalarla öğrenciler arasındaki bu ilişkinin temelinde özgür bir tartışma 
vardı: görüş birliği hangi çözümlerin benimseneceği konusunda değil, hangi sorunların tartış1lacağ1 konusundaydı.” (Natali 2013: 23).

Bugüne kadar yaygın Platon okuması Raffaello'nun freskinde Platon'la Aristoteles ellerinin farklı yerlere işaret ettiğini görmeye bizi koşullandırdı; artık freskte Platon'la Aristoteles'in göz göze olduklarını da fark ettirecek bir okumanın vakti gelmiştir. 


\section{KAYNAKÇA}

BRANDWOOD, L. (1992). "Stylometry and Chronology", The Cambridge Companion to Plato, ed. Richard Kraut, pp. 90-120, Cambridge: Cambridge University Press.

BURNYEAT, M. (1985). "Sphinx without a Secret", New York Review of Books 32(9): 30-36.

CICERO (1933). Academica, Massachussetts: Harvard Üniversitesi Yayınları.

DIOGENES LAERTIOS (2003). Ünlü Filozofların Yaşamları ve Öğretileri, çev. Candan Şentuna, İstanbul: Yapı Kredi Yayınları.

DITTENBERGER, W. (1881). "Sprachliche Kriterien für die Chronologie der pllatonischen Dialoge", Hermes, 16: 321-345.

GONZALEZ, F. J. (1995). "A Short History of Platonic Interpretation and the 'Third Way'", The Third Way, New Directions in Platonic Studies, ed. Francisco Gonzalez, pp. 1-24, Rowman \& Littlefield.

GONZALEZ, F. J. (2009). "Caring and Conversing about Virtue", Reexamining Socrates in the Apology, eds. Patricia Fagan \& John Russon, pp. 117-167, Evanston: Northwestern University Press.

GUTHRIE, W.K.C. (1975). A History of Greek Philosophy, Vol. IV: Plato - The Man and His Dialogues: Earlier Period, Cambridge: Cambrdige University Press.

IRIGOIN, J. (1997). Tradition et Critique des textes grecs, Les Belles Lettres, Paris.

LONG, A. A. \& SEDLEY, D. N. (1987). The Hellenistic Philosophers, Cambridge: Cambridge University Press.

MULHERN, J. J. (1971). “Two Interpretative Fallacies”, Systematics, 9(3): 168172.

NAILS, D. (1998). "The Dramatic Date of Plato's Republic", The Classical Journal, 93(4): 383-396.

NATALI, C. (2013). Aristotle - His Life and School, ed. D. S. Hutchinson, Princeton Üniversitesi Yayınları.

PETTERSSON, O. (2017): "Dangerous Voices: On Written and Spoken Discourse in Plato's Protagoras", Plato's Protagoras: Essays on the Confrontation of Philosophy and Sophistry, ed. O. Pettersson \& V. Songe-Møller, pp. 177-198, Springer.

PLATON (1944). Devlet III. Kitap, çev. A. Erhat, İstanbul: Maarif Matbaası. 

Klasikleri. $^{26}$

PLATON (1944). Devlet III. Kitap, çev. A. Erhat, İstanbul: Cumhuriyet Dünya

PLATON (2006). Devlet, çev. S. Eyuoğlu \& M. A. Cimcoz, İstanbul: İş Bankası Kültür Yayınları.

PLATON (2007). "Devlet," çev. H. Demirhan, Platon: Toplu Diyalogları - I, ss. 391-735, Ankara: Eos Yayınevi.

PLATO (1997). Complete Works, Edited by John M. Cooper, Associate Editor D. S. Hutchinson, Indianapolis/Cambridge: Hackett Publishing.

RECCO, G. (2010). Athens Victorious - Democracy in Plato's Republic, Lexington Books, Lanham.

RUSSON, J. (2019). Politics, Money, and Persuasion: Democracy and Opinion in Plato's Republic, (forthcoming).

SALLIS, J. (1996). Being and Logos, Reading Platonic Dialogues, İndianapolis: İndiana Üniversitesi Yayınları.

SCHLEIERMACHER, F. D. E. (1836). Introductions to the Dialogues of Plato, trans. William Dobson, Cambridge: Deighton.

SCHOENBAUM, S. (1966). Internal Evidence and Elizabethan Dramatic Authorship; An Essay in Literary History and Method, Northwestern University.

THOUKYDIDES (1942). The History of the Peloponnesian War, Oxford: Oxford Üniversitesi Yayınları.

TIGERSTEDT, E. N. (1974). The Decline and Fall of the Neoplatonic Interpretation of Plato, Societas Scientarum Fennica, Helsinski.

TIGERSTEDT, E. N. (1977). Interpreting Plato, Uppsala: Almqvist \& Wiksell.

WIELAND, W. (1982). Platon und die Formen des Wissens, Göttingen: Vandenhoeck \& Ruprecht.

${ }^{26}$ Bu baskı Erhat 1944 çevirisinin 1998'e “uyarlanmış” ve Türkân Tunga'nın Devlet IV. Kitap'la birleştirilmiş şeklidir. 